\title{
Frances Hodgkins goes to Market
}

\author{
PAMELA GERRISH NUNN
}

\begin{abstract}
The marketplace is a recurring subject in the work of artist Frances Hodgkins (1869-1947). Her handling of it over the years, and in different contexts, shows how she developed as a professional artist and with what trends she linked herself. The market can be seen in the work of British artists (e.g., Charles Worsley) of whom she will have been aware before she left her home country, as well as in the work of French ones (e.g., Camille Pissarro) whom she will have discovered once she went to Europe. A study of her use of this motif is essential to locating her as a New Zealand artist who became a European artist.
\end{abstract}

While Frances Hodgkins was an apprentice artist in Dunedin, she drew on the habits that she saw around her and the knowledge she could glean of art in Europe to formulate an artistic practice that would give her a New Zealand career. Once she was overseas, she encountered many more ideas about repertoire, strategy and patronal taste, some of which required a reappraisal of the assumptions she had brought with her, and enlarged her ambitions to include the prospect of a British career. One of the conspicuous additions to her range of subject matter dating from this point of reorientation was the marketplace, evoked by the first person to attempt an appraisal of her life's work as "the market scenes innumerable."1 This motif forms such a noticeable strand in the fabric of her next 20 years' work that it merits focussed attention, which will be shown to yield valuable insights into her habits, aims and achievement.

Before delving into Hodgkins's use of this motif, a potted history of it will be useful. The marketplace was a theme created for the British public by touristic artists, beginning with preVictorians depicting their own historic towns and the more celebrated towns of Italy and Spain; accordingly, it featured in the output of artists such as William Mueller, David Roberts and J. F. Lewis. It continued in the work of innumerable middle-of-the-road Victorian painters and watercolourists, and by the third quarter of the nineteenth century it was seen, chiefly in Britain and France, as a motif that spoke to national character and the survival of vernacular tradition after industrialisation. This was so whether it addressed gallery-goers as patriotic viewers of their own nation or as curious voyeurs of the exotic other.

The marketplace lent itself to the capture of the essence of locality because it was generally the centre of public activities, combining the ritual and traditional with the spontaneous and unpredictable. In the last quarter of the nineteenth century in Europe, when the department store began to emerge in larger urban centres, the market in smaller towns and cities survived as a persistent sign of the demotic:

It is in the market-place ... that we shall obtain the best idea of the place and of the people. On market mornings and on fête days, when the Place is crowded with old and young,- - when all the old caps of every variety and shape, from the "helmet" to the bonnet rouge, and all the old brown coats with short tails, are collected together,we have a picture the like of which we may have seen in paintings, but seldom realize in life. Of the tumult of voices on these busy mornings, of the harsh, discordant sounds that sometimes fill the air, we must not say much, remembering their continual 
likeness to our own; but, viewed picturesquely, it is a sight not to be forgotten. Here the artist will find plenty of congenial occupation. ${ }^{2}$

Within this subject, some distinctions were emerging by the late nineteenth century which Hodgkins may well have noted. William Matthew Hodgkins will have shared his art knowledge with his painting daughters, and the household kept up with the British art scene through the periodical press and reports from well-connected friends such as Dr. John Scott and his wife. General views of the market within an architectural setting, with their staffage of small figures against historically accurate façades, were becoming old fashioned. These works were more likely to have been constructed in the studio from on-the-spot studies than to have been made sur le motif, as the French phrase had it, and a taste for greater immediacy followed the impact of French impressionism. Scenes with larger, interacting figures more closely observed in situ characterised the "peasant painting" emerging in British and French naturalist art from the 1880s, typified by Walter Osborne's Early Morning in the Market, Quimperlé (1883, private collection). ${ }^{3}$ As they became more elaborate, such compositions could make for a crowdpleasing mix of vernacular detail and anecdote, as in such typical examples as Alfred Glendening's The Flower Market Boulogne (1897, Russell-Cotes Art Gallery and Museum). And in an Orientalising play on this trend, a location exotic to western Europeans made for greater, more sensational effects: two British artists whom Hodgkins admired, Arthur Melville and Frank Brangwyn, were noticed for this sort of thing. A slightly different note, attractive to both sentimentalists and realists, was struck by isolating a single figure or action within the market scene, producing a simple genre scene in costume, for example Walter Langley, The Best in the Market (1881, Bowerman Charitable Trust). ${ }^{4}$

While her situation in Dunedin did not offer Hodgkins the marketplace as a prime subject, ${ }^{5}$ the city art collection included the large Stanhope Forbes oil Preparing for the Market, Quimperlé (1883, Dunedin Public Art Gallery [DPAG]), and at the annual exhibitions around New Zealand to which she was increasingly contributing from 1890, she could have observed the practice of Charles Worsley (1862-1923), for one, whose regular travels around the established painting spots of Western Europe yielded many market scenes duly exhibited in the New Zealand centres. She may also have had her attention directed to this subject by her earliest personal contact with European art, the Italian Girolami Nerli, although he does not seem to have used the motif himself until he left New Zealand. ${ }^{6}$ His habit of working outdoors so as to gain authenticity and immediacy certainly did help to shape her practice.

Once in Europe, Hodgkins had this motif established in her practice by one of her earliest contacts, Norman Garstin. Garstin, a member of the Newlyn community who conducted annual summer schools in France, had also written extensively in the British art press about the kind of art he favoured. While he may have been one of the first artists to make a regular income stream out of the Continental summer school, he was essentially enacting an idea already articulated in such publications as Henry Blackburn's Breton Folk: An Artistic Tour of Brittany (1880). ${ }^{7}$ In 1901, he was joined in his summer school in the Seine-side village of Caudebec by Hodgkins and her compatriot Dorothy Kate Richmond, who had recommended it to the newly arrived Dunediner. Despite the town's other attractions, ${ }^{8}$ for Garstin's group the market scene was the primary focus, still "the great centre of business, gossip, intrigue, and the life in general of the inhabitants of this kingdom." 9 The French production of postcards of the better known markets in the first decade of the twentieth century testifies to the widespread appeal of this site to all kinds of visitors, and these images indicate the ingredients that became the staple elements of the scene as painted by numerous artists: stalls, heaps of specific commodities, 
browsing shoppers often in traditional dress, and anecdotal exchanges between buyers and sellers. There is evidence that Hodgkins and her associates took their own photographs of these scenes to work from after the event; surviving examples show several of the elements that feature in the European market scene that Hodgkins developed from this point as a staple element of her repertoire (figure 1). ${ }^{10}$ Whether the close resemblance of these postcard images to contemporary paintings is due to the logistical possibilities of such situations, or to a more intentional imitation on the part either of artists or commercial photographers to each other, is an intriguing question that seems impossible to answer.

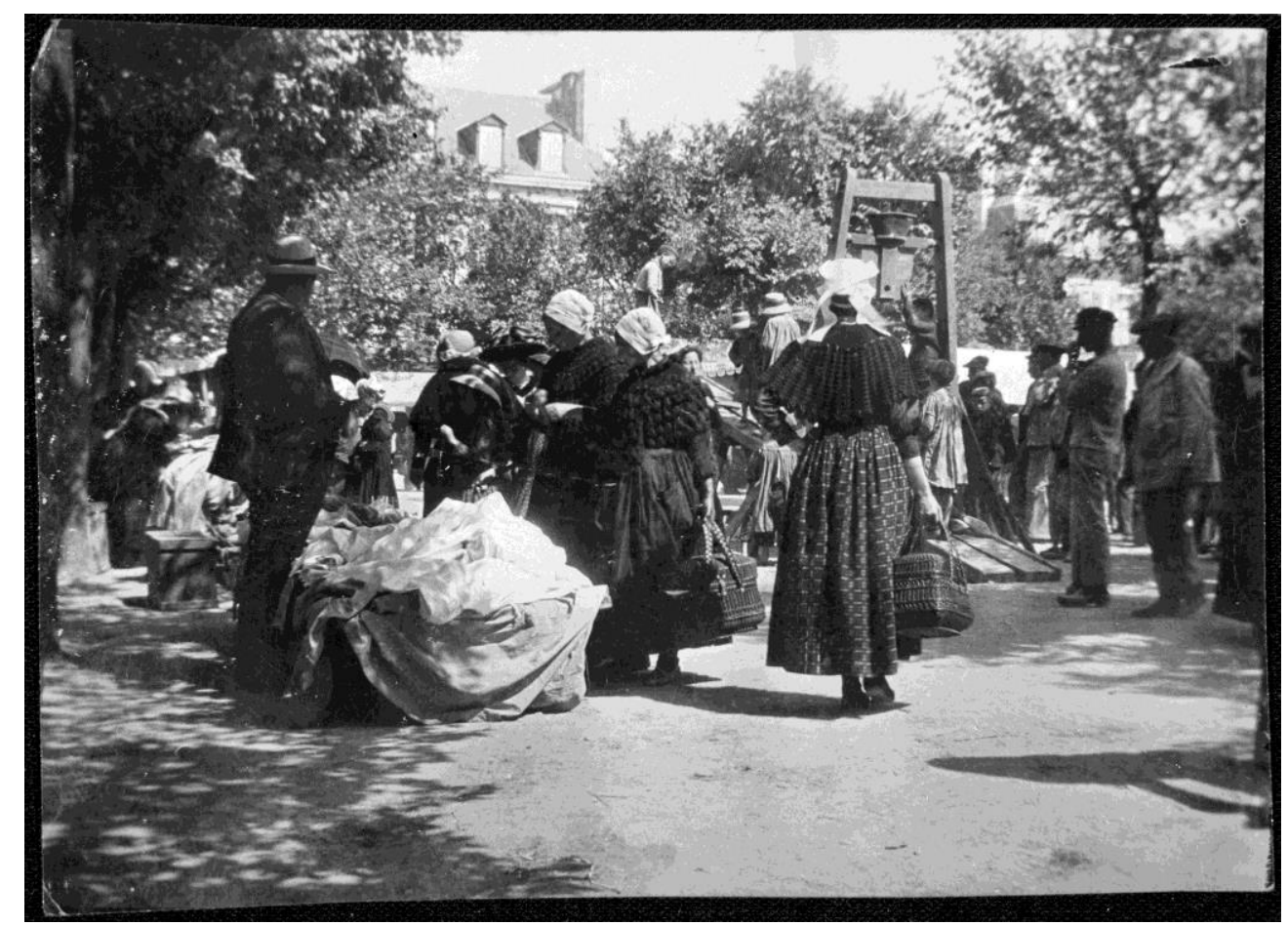

Figure 1. Katherine Ritchie (Miss), Market Scene in Concarneau, Brittany, France, Photographs associated with Frances Hodgkins, Ref. 1/2-124276-F, Alexander Turnbull Library.

These are, however, the elements found in Garstin's treatments of this theme, such as a small watercolour that may very well be from this first trip that Hodgkins made with him, The Market, Caudebec (figure 2). This, and a small oil entitled Breton Women at Le Fouet (undated, private collection), indicate the possibilities he saw in the subject that Hodgkins would explore in her turn. In the former, the artist has taken up a position near a stall selling vegetables, while the single figure of an elderly female shopper at the nearest stall draws the viewer's eye, which then roves over the middle ground behind her to other individual female figures visible in the space between other stalls and the old building giving on to the place. Overall, it recalls the market scenes of impressionist Camille Pissarro, which Garstin probably knew. As Christopher Lloyd points out in his account of Pissarro's market scenes, while they were very specific to the villages he knew, such as Pontoise and Gisor, they may be seen as "part of a more general record of peasant life" which preoccupied Pissarro from about 1879. ${ }^{11}$ Meanwhile, Léon Lhermitte, a more popular French painter of the last quarter of the century, had also produced several well-received market scenes, beginning as paintings exhibited in the Paris salons, subsequently reproduced in the illustrated papers, and enlarged upon by their author as independent engravings. ${ }^{12}$ Such artists as Pissarro and Lhermitte may well have been 
introduced to Hodgkins by Garstin - if so, yet another factor which made him such a formative acquaintance for her at this point.

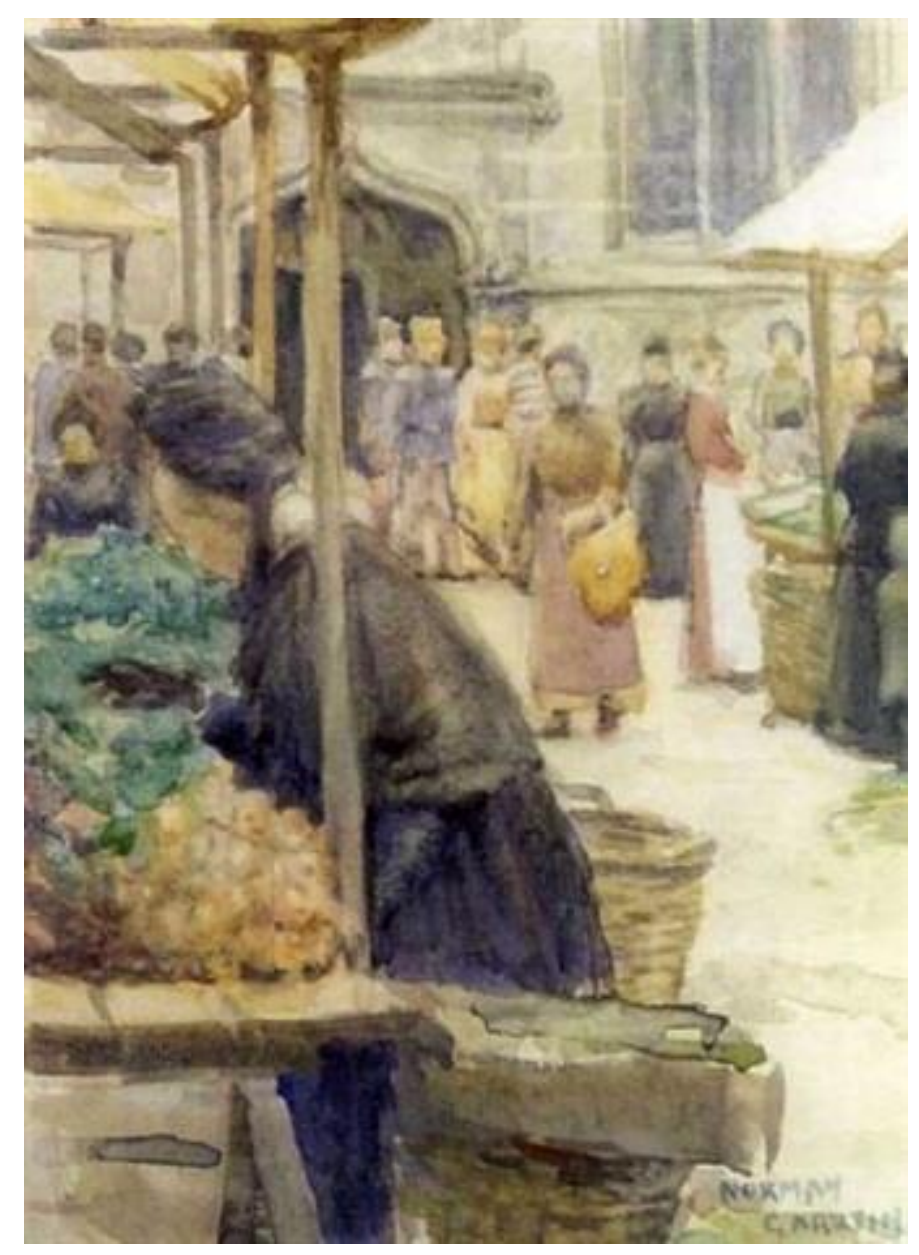

Figure 2. Norman Garstin, Market at Caudebec (1901?), $17 \times 12.5 \mathrm{~cm}$, Ex-James Adam and Sons.

Standing around and taking everything in, the foreign art students mimicked the normal form of behaviour at the market, though with their language, their dress, their sketchpads and their easels marking them out from the locals. The novelty of working in these settings can be gathered from Hodgkins's letters home. Describing the aforementioned Caudebec to her mother in August 1901:

It is useless trying to paint a market scene, we have all tried and then sadly turned our backs on its fascinations. We found we always came home so cross and irritable after a morning spent in the market that Mr Garstin mildly suggested we should cease wrestling with it. ${ }^{13}$

This was evidently only a beginner's exasperation, because the market became a core part of the repertoire she developed on this trip, and remained so for many years to come. Hodgkins hints at the aspects of the scene that especially caught her attention: 
Some of the old men wear such beautiful blue corduroy bags that make me ache to paint them, it is a great sight to see them on Market day (every Sunday) the whole town is covered with little canvas booths and with the different goods displayed and the babel of noise that goes on, each stallholder crying up their own particular wares. ${ }^{14}$

After this initial excursion, when Hodgkins was in Normandy later that year the market scenes began to flow, with Calves for Sale, Les Andelys (1901, figure 3) reflecting the enthusiasm of the letter quoted above. The viewer looks across the pen where the beguilingly pink animals nestle against the barrier, the buyers and sellers in their blue clothing standing behind them to form an effective colour contrast. The rest of the market provides a bustling background beyond, with the blue note of the local costume and the blond colouring of the architecture completing a simple but vibrant scheme. The practicalities and possibilities of such work are hinted at in other letters:

Two days ago we made our farewells to our beautiful Arlesian friends - in the market where we would paint every day. ... [The poulterer] was a nice woman and we were grateful for little attentions in the way of chaufrettes [sic] to keep our feet warm, cups of black coffee on cold days and various little kindnesses. I must tell you, this market is a huge whitewashed building lighted from above round which the different tradeswoman have their stalls, imagine the colour with the sun overhead - the butcher's stall, made to look as red as possible with crimson coloured tables and awnings to help out the illusion of a plentiful supply of meat - this stall is flanked by the poulterer on the left who is always in a cloud of feathers and distressed cackling and gurgling from the strangling victims. Then comes the green grocer with her two pretty daughters always beaming from behind a barricade of pumpkins, melons, pomegranates, figs and green stuff. This is my favourite stall and I have made many studies of it. Then there is a corner given up to pottery and earthenware of many colours and shapes. ${ }^{15}$

The appeal of the specificity of produce - fish, pottery, livestock, flowers - which in French markets might be sold in a particular area of the marketplace or even on its own particular day, gave a potential variety to the market motif which Hodgkins was quick to seize as she moved around France and Italy during the next twelve months, and to continue in her reiteration of the motif over the next few years. Titles of known works, some currently untraced, suggest her grasp of this potential, from Vegetable Stall, Dinan (unidentified, exhibited 1902) ${ }^{16}$ and Untitled (The Watermelon Seller) (1901-03, Auckland Art Gallery) through The Flower-girl, Bruges (1903, whereabouts unknown) to The Fish Market, Arles (1901, whereabouts unknown). Her Pottery Market (1902?, ex-Jonathan Grant Gallery) reiterates the approach of the Andelys scene, with the produce's specific qualities displayed in the foreground to the viewer's gaze while a figurein this case the stallholder rather than a prospective customer-occupies the upper half of the picture space. Though she merely minds the stock, she bears comparison with the active peasant women of Pissarro, for whom the market was "the end result of the peasant's labour" in which both women and men played "their role in a class structure and in a capitalist economy."17 Hodgkins's preference seems to have been, likewise, for some exchange between occupants of the scene, but here she has at least achieved a proximity to the trader that draws in the viewer as a privileged observer. 


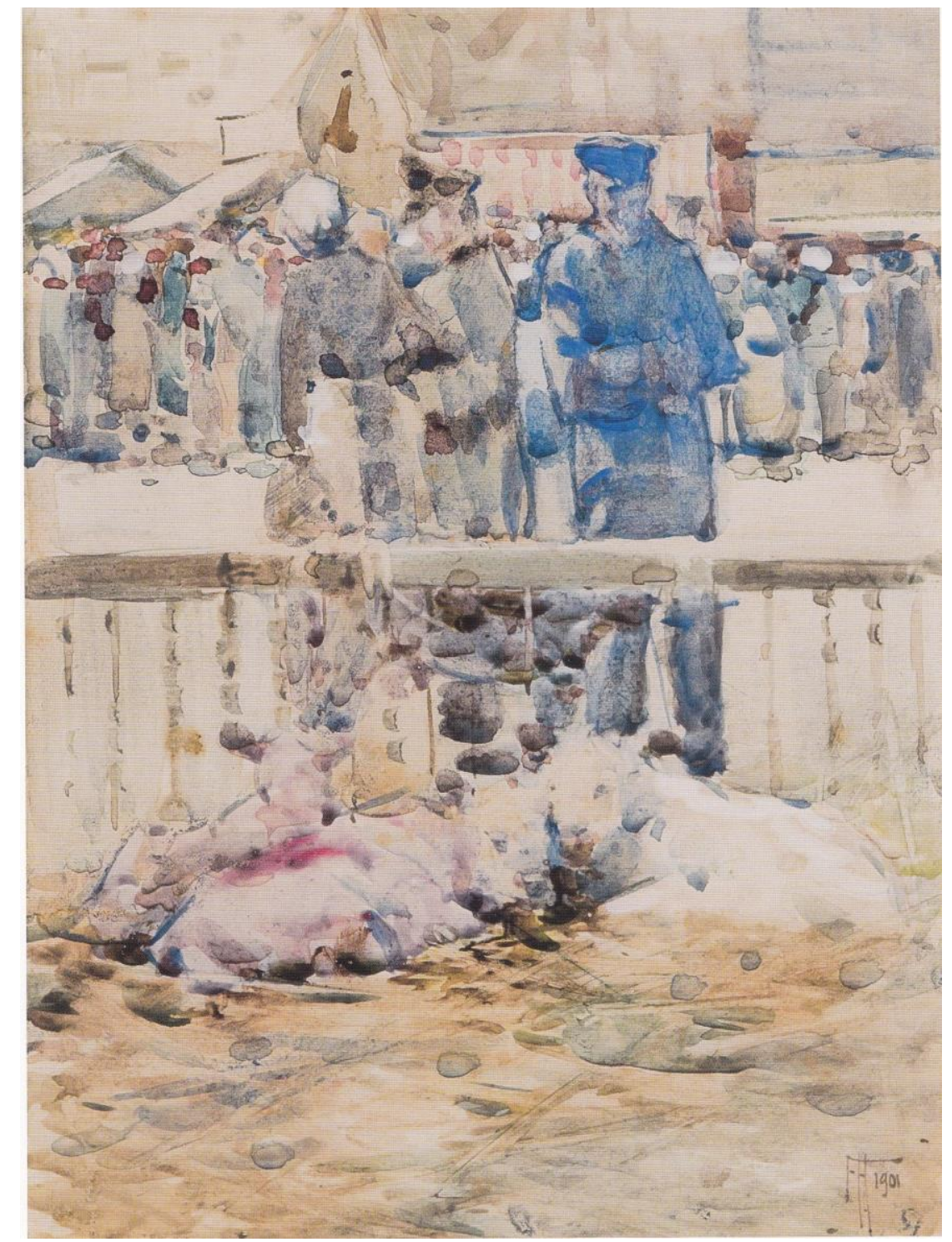

Figure 3. Frances Hodgkins, Calves for Sale, Les Andelys (1901), $20 \times 15.5 \mathrm{~cm}$, private collection.

It may have been an art of the picturesque that Hodgkins was pursuing, but it is the domestic picturesque, rather than the reports of the artist-adventurer who has fiercely strange and dangerous things with which to dazzle his viewers. ${ }^{18}$ The format of these modest and accessible works is consistent, with a recurrent size of $36 \mathrm{~cm}$ by $26 \mathrm{~cm}$. Typically, the viewer stands a few paces before a stall, looking into a vertical space, where a few browsing or bargaining figures of women can be seen, perhaps accompanied by girls. The stallholder standing to one side or behind the display of produce may be male or female, with the identity of the merchandise articulated by the brushwork and perhaps confirmed by the title. Most figures animate the scene but do not address the viewer, and may not even face the viewer, who is thus cast as a browser or prospective customer, as in A Busy Corner in Arles (1901, Harris Art Gallery, Preston), invisible for the moment in which $\mathrm{s} /$ he can enjoy the freedom to gaze on a picturesque sight. Where this dynamic is intentionally different, the more than usually sketchy technique suggests that the conditions dictated the emphasis in any specific work. The more elaborate scenes may have been composed after the event into scenes of exhibition appeal from the separate elements 
the artist was able to produce sur le motif, whether settings such as Gateway on the Riviera (1901, MTG, Hawke's Bay), individual figures such as Stallholders (undated, Wellington City Council) or figure groups such as McCormick's misidentified Moorish Market (in fact a French scene, most probably Arles, whereabouts currently unknown). ${ }^{19}$ The technique Hodgkins had adopted by this stage allowed for rapid work which could be polished later, and she refers more than once in the account of herself she gives her family to working up back in her lodgings pieces that could not be completed on the spot. ${ }^{20}$ This response, to change her style to fit the situation, became a habit that explains the diversity of technique to be seen in Hodgkins's entire body of work.

Hodgkins continued this basic pictorial idea as she parted company from Garstin and progressed with Richmond along the northern Mediterranean coast of Italy (Market-Place, San Remo [1902, Te Papa Tongarewa]; San Remo Market [1901, private collection, figure 4]). Several months in England then saw her turning to a range of other subjects and activities, after which Dinan, a small Breton town to which she went with the Garstins in July 1902, prompted a large batch of market-based works which Dunedin gallery-goers were able to see a few months later:

Dinan is a first-rate place - a variety of everything - old streets, peasant women, fruit stalls, river scenery, feudal castles and two "dashing" cavalry regiments.... The great event of the week is the Thursday market, more especially the cattle market - cows, pigs, sheep etc. pour in from the country and muster in great force in the Place. The cows stand in tight rows flank to flank (from a painting point of view it is disappointing — heads or tails). ${ }^{21}$

Once again, Hodgkins showed a greater keenness to take the market as her subject than the historic street scenes and ancient buildings well known as tourist attractions (though there are some such works, which increased in number as the years went by). ${ }^{22}$ She claimed to her mother that she was not by an means taking the easy option, as these works were "the fruit of a great mental effort, my nerves are stretched and my eyes are driven mad by the swarming of the crowd, all my senses are alert, I observe everything, on the look-out for effects and the relationships between things." (This assertion was made again a few months later almost wordfor-word to her sister when trying to impress upon Isabel how much labour these pieces represented.) $)^{23}$

One of the sources of strain was the harsh treatment of animals she witnessed at the market, which she had hinted at in her letters home and, perhaps on account of this, the Dinan works show little livestock, instead depicting the various produce on sale, from meat and fish (The Meat-Market, Dinan; The Fish Market, Dinan [both 1902, whereabouts unknown]) through vegetables (The Market Place, France, [1902, DPAG]) and flowers (The Flower Market/Selling Flowers before a Fete Day [1902, whereabouts unknown]) to the more unexpected and locally specific (Confetti Seller, Dinan [1902, whereabouts unknown]). From this point, figures become more prominent: vendors sitting at a stall, standing behind their produce bargaining, accosting prospective clients; female shoppers sizing up rival vendors' setups (Market Scene [1902, DPAG]) or turning to leave, their purchases made (Marketing, Dinan [1902, Aigantighe Gallery, Timaru]). The loitering which she had to be prepared to do in the marketplace may have been accommodated by the individual women who became more conspicuous in Hodgkins's compositions, absorbed in their selling, buying or bargaining but permitting the artist to hover nearby (figure 4). The artist - and viewer-gets gradually nearer the hub of the essential marketplace exchange, the sale, as Hodgkins can be presumed to have 
got better at insinuating herself into these situations that only twelve months earlier made her "cross and irritable." Often, she stands across the alleyway from her subject (as in Women in a French Market [c. 1903, DPAG]) or, like Pissarro, she pauses at the elbow of an individual seller or buyer, giving the viewer a place in the crowd. While she only gradually learned to capture the mobility of this everyday life, through a nice judgment of distance and judicious loosening of brushwork Hodgkins became capable of conveying the heterogeneous throng and the visual kaleidoscope which was an essential part of the appeal these situations had in real life. As she settled into it, Hodgkins was evidently able to find practical positions and an amenable attitude that allowed her to drink in the scene on behalf of her prospective audience without antagonising its regular occupants. Always the image is constructed with a foreground space through which the viewer can imagine themselves entering the scene. Where some local feature such as architecture (Market-Place, San Remo, [1902, Te Papa Tongarewa]) or costume (Marketing, Dinan [1902, Aigantighe Gallery, Timaru]) could make a distinctive contribution to the basic motif, Hodgkins allowed it to do so-perhaps anticipating the limits of this one subject's appeal in the restricted art market of her home country, already fed by numerous artists with a similar agenda to her own, with whose works hers would be in competition.

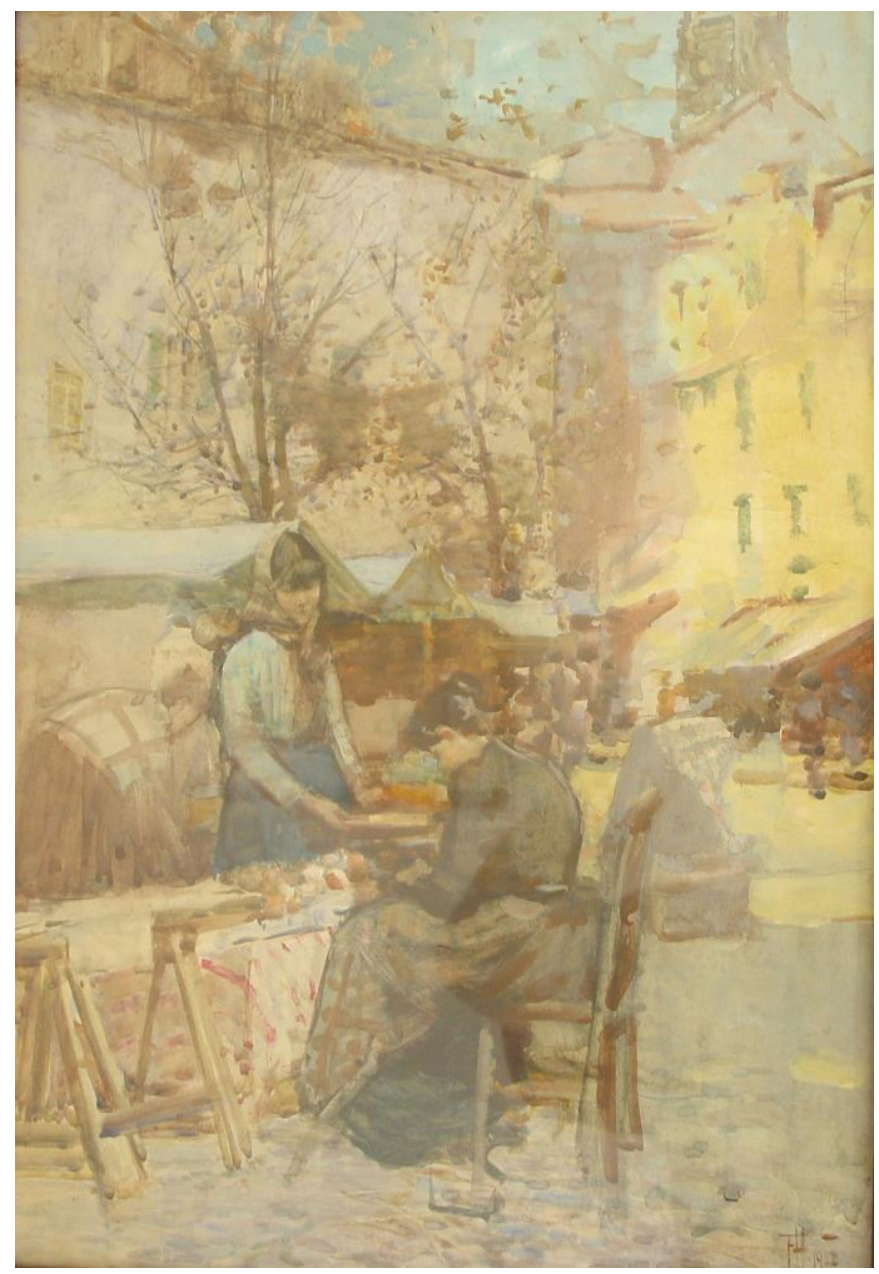

Figure 4. Frances Hodgkins, San Remo Market (1902), $41.9 \times 21.2 \mathrm{~cm}$, private collection, New Zealand. 
The reception given these works in her home country shows, indeed, that the artist trod a fine line trying to exploit established trends and still offer something fresh. The local reviewer of the annual Dunedin exhibition in November 1902 observed that "there may be some monotony of subject in [Miss Hodgkins's] pictures" (though he praised In the Market-Place, San Remo for its technique). ${ }^{24}$ Of sixteen exhibits, all but one were scenes of small-town life in France or Italy, and almost half featured markets. The same reviewer waxed lyrical the following year over one of Worsley's typical exhibits at this same venue, saying:

one is naturally attracted at once by Mr Worsley's fine work The Market Place, Cordova, Spain, and most people will return again and again to study the great market square with its crowd of quaint, jostling figures, its great umbrella-like screens, the hucksters' stalls, and the charming suggestion of warm sun-lighted distance afforded by the glimpse of blue sky and bit of white roof. ${ }^{25}$

One wonders exactly what Hodgkins's misstep was (not simply failing to include Spain on her itinerary, surely).

Apart from the Dunedin showing, in October 1902 several of these Dinan market scenes were exhibited in a group show at (John) Baillie's gallery in London including works by Margaret Stoddart, Dora Meeson and Grace Joel. Some could then be seen again at Doré's gallery in November - a flurry of exhibition indicating that Hodgkins believed this subject matter was likely to sell in both hemispheres. But the reappearance of some of these works in the show that she and Richmond put on in Wellington, on their eventual return to New Zealand at the end of 1903, reiterates that the appetite for it was not limitless, despite her marked investment in this particular subject. ${ }^{26}$

A sideways look at the work of contemporaries roaming the same territories at this time shows how widespread the market habit was and thus how numerous the competing works. There was one of the most successful female artists in late-Victorian Britain, Helen Allingham, turning in 1901-02 to the market stalls of Venice to refresh her repertoire. There was Christchurch native Sidney Thompson, spending 1901-05 gathering very similar material to Hodgkins. There was Englishwoman Ethel Carrick, married to Australian Emanuel Philips Fox, in Caudebec around the same time as Garstin and Hodgkins and showing the results at the Royal Academy exhibition in London in 1903 (Market Day, Caudebec [1901-03, whereabouts unknown]). There was Grace Joel, Hodgkins's Dunedin contemporary who had also come under the influence of Nerli, producing Marketing at Etaples around 1901 in more than one iteration. ${ }^{27}$ And, not surprisingly, the list can be extended with the names of New Zealanders abroad advised by Hodgkins: Owen Merton's Fruit Stall, Port Said (1907, Te Papa Tongawera), Maude Burge's Pig Market, Montreuil (c. 1912, Te Papa Tongawera) and Maud Kimbell Sherwood's extensive use of the motif over the years (e.g., The Chili Market, Tunis [1927-28, private collection]) come readily to mind. ${ }^{28}$

So if the appeal of her works was limited, perhaps it was because Hodgkins's locations were the expected or predictable places, and yet not the most glamorous of these such as Nice or Venice (these came later). Her itineraries seem not to have been determined by her own programme so much as by chance, finances and others' initiatives, with Norman Garstin's movements in particular remaining relevant to her decisions. Thus her opportunity to venture to North Africa at the end of 1902: though this plunge into the marketplace's Orientalist iteration may have been daring in her own regard, it had already attracted the attention not only of Garstin but of Orientalists such as Alberto Pasini and his British followers Arthur Melville and Frank Brangwyn, a fact that was reflected by Garstin's article of 1897 recognising Tangier 
as a location attractive to European artists, in a publication the Hodgkins family was likely to have read in Dunedin. ${ }^{29}$

In Morocco, Hodgkins typified even more extremely the artist as the interested outsider observing the enactment of the foreign picturesque. Though the market was usually one of the easiest places for such outsiders to find subject matter, make useful contacts, and absorb some local colour as crowds gathered, lingered and could be easily observed, the travelling artist, while being an outsider, was also an interloper. When they were in their own country, they were unlikely to raise that particular tension that the obvious foreigner could so often provoke. So, artists such as Australian Tom Roberts painting Christmas Flowers and Christmas Belles (c. 1899, Manly Art Gallery and Museum) or Briton Laura Knight sketching Whitby Market (c. 1900, private collection) were on home ground and, though purveying the picturesque to urbanites, could not be resented as uninvited voyeurs liable to violate norms of which they were ignorant. But the visiting foreigner cut a more complex figure-a situation which was tested further when Hodgkins ventured beyond Europe.

The four-and-a-half-month trip to Morocco (December 1902-April 1903) presented new conditions. Hodgkins spent time in two towns, Tangier and Tetuan. She would have had-from Garstin especially - hints as to the best sites and situations, and she put up at a guesthouse not far from the main market, which she clearly looked to as her main site of production. However, at first we felt bewildered and a trifle nervous at the crowds of lean, brown fierce looking men but they are so busy coming and going and farthing splitting in the market that they never turn a head to look at us. . . . Apparently there is no method in the market, donkeys saddled and unsaddled are ubiquitous and anyone with anything to sell sits down and sells it. There is a corner devoted to cobblers, dwellers in tents who seem to eke out a miserable existence patching each other's old shoes. Then there is a row of Arab women squatting like Sybils with their impenetrable leathern looking faces peering out of their white burnous - they sell pottery and I hope to get some pictures here if I have any luck. It is all so crowded that I don't expect to get much done in the streets. Mr [Alfred] East said he had to take his models in to courtyards and quiet places. Mr Garstin was right, no gorgeous east here-no oriental riot of colour - all browns and whites and muddy creams with here and there a splash of crimson and orange and the better class Moors making blots of indigo in their handsome blue cloaks. ${ }^{30}$

The liminal spaces that stalls could occupy here, not necessarily in a dedicated forum but at a street corner, an archway or point of entry and exit to/from a hub of the city, must have exaggerated the conspicuousness of the obviously foreign woman sketching or painting. To further her aims, expressed in this same letter as "to rise early and paint Brangwyn pictures in the market," Hodgkins luckily acquired "a boy to shepherd us about."

Her stated hope, of getting "a good portfolio of sketches" that "will pay me over and over again," 31 is manifested in numerous scraps, unfinished sketches and beginnings of pictures surviving from this trip. The conditions characterising it were reported back home: "In Tangiers, people have a great dislike to-indeed, a religious scruple against-having their portraits taken. Consequently the artist was only able to get some glimpses of street scenes, some marketplace groups, and sketches of the little picturesque children." ${ }^{32}$ This is reflected in In an Eastern Market (1903, whereabouts unknown), in which a number of women sit on the ground in an open area surrounded by their produce, which spills over the foreground towards 
the viewer's feet. Nearly all the figures have their backs turned to the viewer, while one of the women peers out from under her burnous directly at the artist, as if to say, "What are you looking at?" Most of the Moroccan scenes reflect this contingency, as if grasped in the moment, with figures on the move regardless of the artist's own preferences. In numerous street sketches children stare curiously at the white woman with her easel and sketchbook as they pass through the picture space, her figure making absolutely no sense in their own world. In the impressive The Dye-yards (1903, private collection) this uncomprehending gaze is what rivets the viewer, and a quizzical child looks out from Arabs, Tetuan (1903, Aigantighe Gallery, Timaru), Orange-sellers, Tangier (1903, Te Papa Tongarewa) and other Morocco works.

The fine art of blending in while securing a good picture was of course an occupational challenge to the plein-airist on foreign ground, male or female. Though the viewpoint of Melville's Cairo Bazaar (1882, Berwick Museum and Art Gallery) presupposes the artist standing right in everyone else's way, his impressive later depictions of the street markets of Tangier offer a solution to street-level hubbub that seems absent from Hodgkins's thinking: in The Green Minaret, Tangier (c. 1890, private collection) and Tangier (1893, private collection), an elevated viewpoint must have provided him a position from which to work at his own pace, unobserved and unharassed. Perhaps he had local assistance in this respect, and it was not want of imagination but want of opportunity that determined Hodgkins's position.

She would have done well to bear in mind Garstin's stated caution that when the artist visited these parts "he is apt to mistake the freshness of his surroundings for something fresh and striking in itself, forgetting that it is only fresh to him," 33 for she gathered a portfolio of subject matter very like that which the artists preceding her had taken away-excepting the harem, an Orientalist motif that would have been alien to Hodgkins's temperament and to the taste of her New Zealand public. As Brangwyn had done (1888, 1893), she captures many children, a few women and more men buying and selling - fruit, vegetables, pottery - in the bright North African sunshine bleaching the streets and walls of the city. ${ }^{34}$ Under the circumstances, the best known of these, Orange Sellers, Tangiers (1903, Olveston), is quite an achievement. ${ }^{35}$ Moreover, it has at least three companions, The Market, Tangiers or Pottery Market, Tangier (1904, private collection), Orange-Sellers, Tangier (1905, Te Papa Tongarewa) and The Onion-Seller, Tangier (1903, DPAG), which echo Brangwyn's paintings done in Tangier and Haifa (Israel). (Tantalisingly, it is not known if Hodgkins saw his Orange Market, Jaffa and Orange Market, Algeciras on show at the Whitechapel spring exhibition on her return to London, when she turned to the task of working up her haul of Moroccan work. ${ }^{36}$ ) The figures (from whom she keeps a certain distance) are somewhat cursory in treatment, these works' principal feature being the produce, heaped or spilled over the foreground in a manner very like that she had developed in her first forays into this subject in the small towns of France and coastal Italy. Her watercolour may lack the sonorous colour of Brangwyn's oil but it has the advantage if fluency.

The second Moroccan city Hodgkins spent time in, Tetuan, she found more conducive to work after "noisy shrieking Tangier," 37 although even here her forays into the market soon yielded to the greater ease of back street work on shops and street children. Not surprisingly, on her return to England she needed "a long quiet fortnight working hard at my Morocco pictures" in order to generate ten works to show at the Fine Art Society. ${ }^{38}$ The greatest risk in this practice is the loss of immediacy and perhaps accuracy, but Hodgkins's New Zealand viewers were unlikely to look beyond the exoticism of the subject matter in which, as has been seen, Hodgkins had great faith. In some proof of this, Orange-Sellers, Tangier was purchased from 
the 1905 Wellington annual exhibition by the Academy of Fine Arts to add to its growing collection of contemporary art being amassed against the day that New Zealand should establish a national art collection.

Perhaps Hodgkins was overinvested in this subject by this time: when there was talk next in her circle of going to the Netherlands during the summer of 1903, her response was not to bother to go to Holland because "there is plenty to keep me busy here [in Bruges] in the markets." ${ }^{39}$ She had not been to Belgium before, but Bruges was an established favourite amongst marketplace painters and was, for instance, the frequent location of Scottish painter Flora Reid's marketplace compositions, which Hodgkins would have known from the annual Academy Pictures and elsewhere in the British press. Hodgkins's works from this city are not well known now, but exhibition titles indicate a greater emphasis on individual figures drawn from the marketplace (The Rag-Seller, Bruges; The Flower-girl, Bruges, both 1903, whereabouts unknown).

When she did, in fact, move on to the Netherlands to paint once again alongside Richmond and Garstin, conditions were evidently sometimes fraught, showing that this well-worn subject matter did not necessarily become more accessible as the years went by. Writing home from Delft, in September 1903, Hodgkins recounted:

I sat down in front of a fish stall this morning to paint and the old fishwife came up and shook her fist at me and said, "You don't paint me, you Englander" and she collected such a crowd I thought it wiser to move on. The boys have been dreadfully troublesome, throwing things at us and one day I was mobbed and had to appeal to the police. ${ }^{40}$

Vivid confirmation of these occupational hazards is given in the correspondence of one of her younger compatriots, Maud Kimbell (later Sherwood), from Concarneau a decade later:

As we entered the [fish market] today they all crowded round us and wanted us to paint them, and one old woman, more persistent than the others, sat down near her basket of fish and began to pose for us, which posing consisted of darning her stockings and returning a few of the polite remarks made to her by the other fishwives. ... We were asked by the others to paint the old woman as ugly as she was, which would bring forth a suitable reply from the old woman. ${ }^{41}$

Other artists already mentioned here, such as Sydney Thompson, were still making use of the market motif, whether in oil or watercolour (Earthenware Market, Concarneau [c. 1916, figure 5]; Morning in the Market, Concarneau [1916, private collection] $),{ }^{42}$ but it is telling that by this time Thompson was as likely to work from a judiciously chosen first-floor hotel room or his own private property as sur le motif in the authentic impressionist manner. In addition, his repeated stance was at a judicious distance from the bustling figures absorbed in their characteristic tasks - intriguing for the gallery-goer, but everyday labour for them. No wonder Vida Lahey, Sherwood's Australian contemporary and a later student of Hodgkins (in 1920), wrote in respect of working in the streets of Paris, "at this hour [8 p.m.] the shops were at last closed and quiet; even Colarossi and the Grande Chaumière look different with doors shut and silent. And one knew that for a few hours the studios were quiet and empty. . This is the time to sketch, no one has time to bother about you.",43 


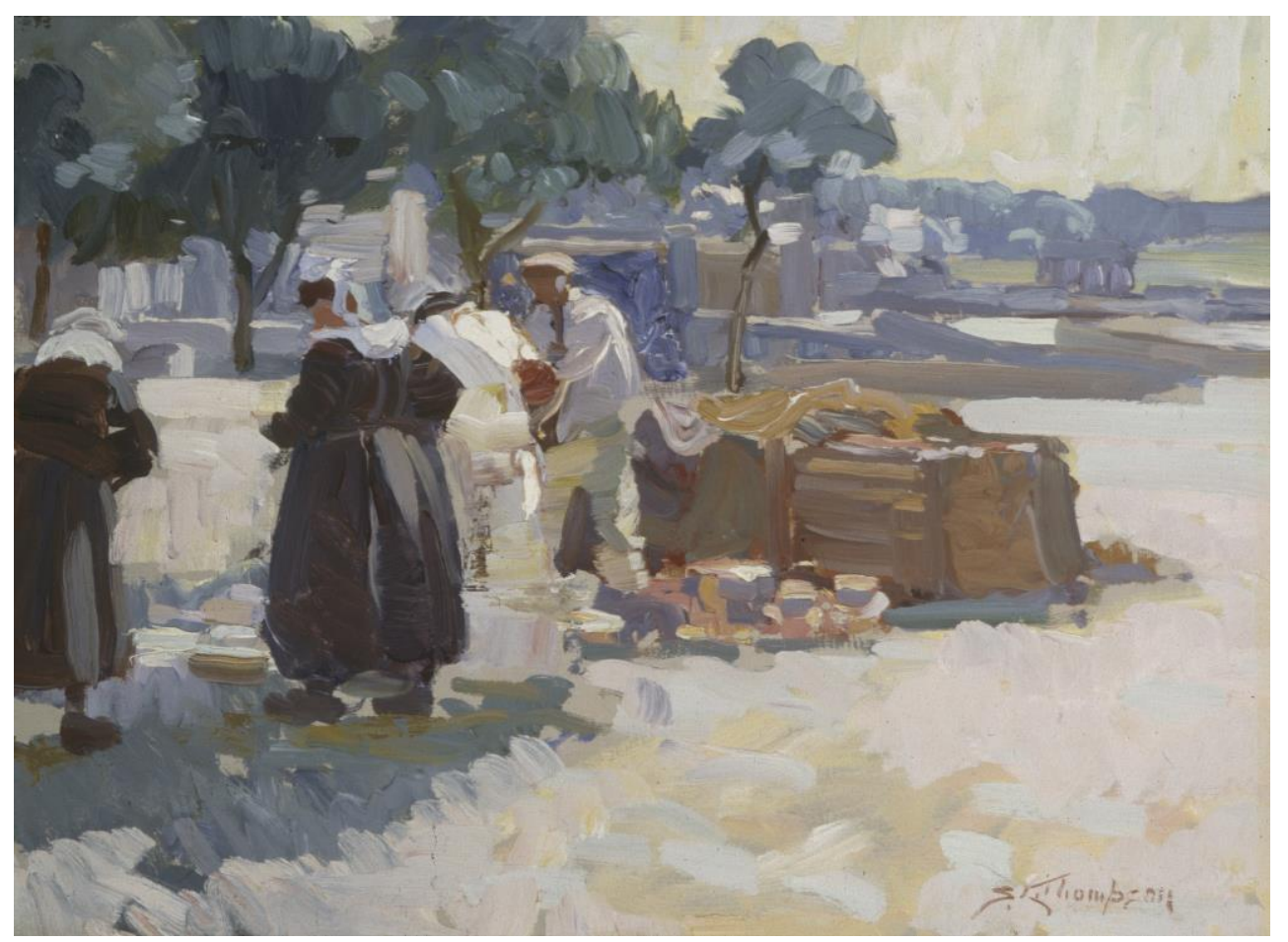

Figure 5. Sidney Thompson, Earthenware Market, Concarneau (c. 1916), $37 \times 45.5 \mathrm{~cm}$, Christchurch Art Gallery Te Puna o Waiwhetu, Marjorie Bassett bequest, 1964.

Although Hodgkins continued to develop her treatment of this familiar set of elements, sales were always a pressing concern, so she felt unable to consign older works to the past. Though the fluency of, say, Checking the Baskets and Loading the Cart (both probably 1909, Auckland Art Gallery) makes her first European pieces look fussy and anecdotal by contrast, Hodgkins constantly re-presented works at exhibition over the years, possibly with altered titles. ${ }^{44}$ Not only did this inhibit her recognisability with the gallery-going public, as her different styles contended for its attention, but it makes it hard to assess the extent and number of her marketplace works. Furthermore, titles do not necessarily reveal a work's subject matter: who would guess that the now untraced Purple and Black (1908) shows a Venetian street stall?

So, for instance, Market Place, San Remo (1902) was on sale in a Paris exhibition as late as 1909, and Tangier, the Market Place (unidentified, 1903) ${ }^{45}$ in Melbourne as late as 1912. In that show of her work, which toured the cultural centres on this side of the world and included some of her very earliest market locations (Arles, Avignon, Dinan), Market Day, Dinan and Vegetable Market, Dinan (both 1902) were singled out for praise, although they were ten years old: it was reported in the local press that the municipal authorities were considering purchasing "one of the large market scenes that have been so keenly admired." 46 So when she returned to Europe thereafter, when she was once again in the position of painting to sell, it is hardly surprising that she leaned on the market motif once more. "I rather want to put in a week or two in the market place of Verona which I hear is splendid for colour," she told her mother in April 1914; "I came to Verona to work in the market place which is one of the most beautiful in Italy and I hoped to get some attractive things here." 
At some points in her career, Hodgkins does seem to have been doubtful as to what to paint next, and as long as market scenes sold or at least attracted compliments, it must have seemed worthwhile to continue them, and to reexhibit old iterations of the theme in pursuit of sales; an explicit instance of this was to occur as late as $1924 .{ }^{48}$ Despite this, Hodgkins was never apparently drawn to the marketplace motif when in Britain, even when she was confined to the southwest during the war and the historic towns of Exeter and Plymouth were accessible; and even when after the war she was restless and footloose with access to Shropshire and Oxfordshire as well as London. Was England insufficiently exotic to her? If so, had she forgotten that its very familiarity would have appealed to the false nostalgia which led so many New Zealand gallery-goers to favour views of Home? She might have done well to recall her old friend Garstin's advice to artists going to Morocco that "the original treatment of a rag-fair in the east end of London" could be as interesting as anything more out of the way. ${ }^{49}$ This indifference is an oddity (unless such works exist presently unidentified), and indicates that Hodgkins's habitual pragmatism could at times be perverse and self-limiting. Despite her often-expressed professional ambition, ${ }^{50}$ over the years she was often without a plan, or ready to discard one plan for another, though frequently bewailing the uncertainties of her situation.

During the war, titles in the public appearances Hodgkins was able to secure for her work indicate that people edged out the market as the most favoured subject matter, and the development of portraiture did, indeed, reorientate her repertoire substantially in the late $1910 \mathrm{~s} .{ }^{51}$ In the immediate aftermath of the war, though, she was uncertain as to how to proceed professionally, and in 1920 her niece Lydia reported to the family that Hodgkins was "longing to find new subjects for her brush." ${ }^{, 52}$ In fact, in that year she can be seen returning to the tried and tested, reworking some of her most substantial market watercolours from the early European years. In the modernist vein that burgeoned in postwar Britain, subject matter was sought rather as a pretext for technical experiment than as the source of a work's meaning. This formalist approach obviated the need for on-the-spot observation, so the market scenes proved handy as bases for stylistic experimentation. Vegetable Stall, France (c.1906, private collection) emerged in quite a new handwriting as Normandy Vegetable Market (undated, Auckland Art Gallery); and Market Scene, Dordrecht (c. 1907, whereabouts unknown) in two other forms, Dutch Children going to Market (undated, ex-Dunbar Sloane) and The Ferry, Dordrecht (undated, Hocken Collections, University of Otago), the first in watercolour and the second in gouache. More instances of this delving into her "back catalogue" seem likely, even if they cannot be substantiated at present. The compositions are so closely repeated that they must have been done from the original sketch or from the watercolour originals still in the artist's possession. By this time in her fifties, Hodgkins must have been weary of the endless forays into the heart of everyday life where she was the perpetual conspicuous outsider, subject to the local vagaries of convention and etiquette and the twists and turns of the weather, and glad to turn to a more interior art drawn out of the artist's inner resources under conditions of her own making. Homing in on the exchange between female figures, all wearing vernacular bonnets which, along with the background architecture, identifies the locations, the new versions use a range of styles, from a Dufyesque lightness of touch and pretty palette to a pseudo-primitivism presented in proto-cubist circles before the war.

The following year, however, Hodgkins resumed her place in the marketplace itself when she turned once more to teaching to support herself. For her summer class in 1921, Hodgkins installed herself in the Breton sardine-fishing town of Douarnenez. Here, the quayside stalls provided motifs not only for her students but for a number of works (figure 6) in which she employed a new, graphic, patterned style that recalls Vuillard rather than Dufy: as its touch 
loses lightness, the palette becomes more sombre and all elements seem to be bound in a mosaic that flattens pictorial space. The visual emphasis is very firmly on the occupants of the marketplace rather than that site as a whole. The space is closed off, with stallholders sitting or squatting amongst their stock in trade, making for a kind of still life scene. While the choice of this motif seems to be harking back to her earlier practice, there is an anticipatory hint in, say, The Rag Market, Douarnenez (1921, Field collection) and Tabac (undated, ex-Art and Object) of the jumble of forms and objects that would become the artist's stock in trade in her ultimate, wartime repertoire of the early 1940s.

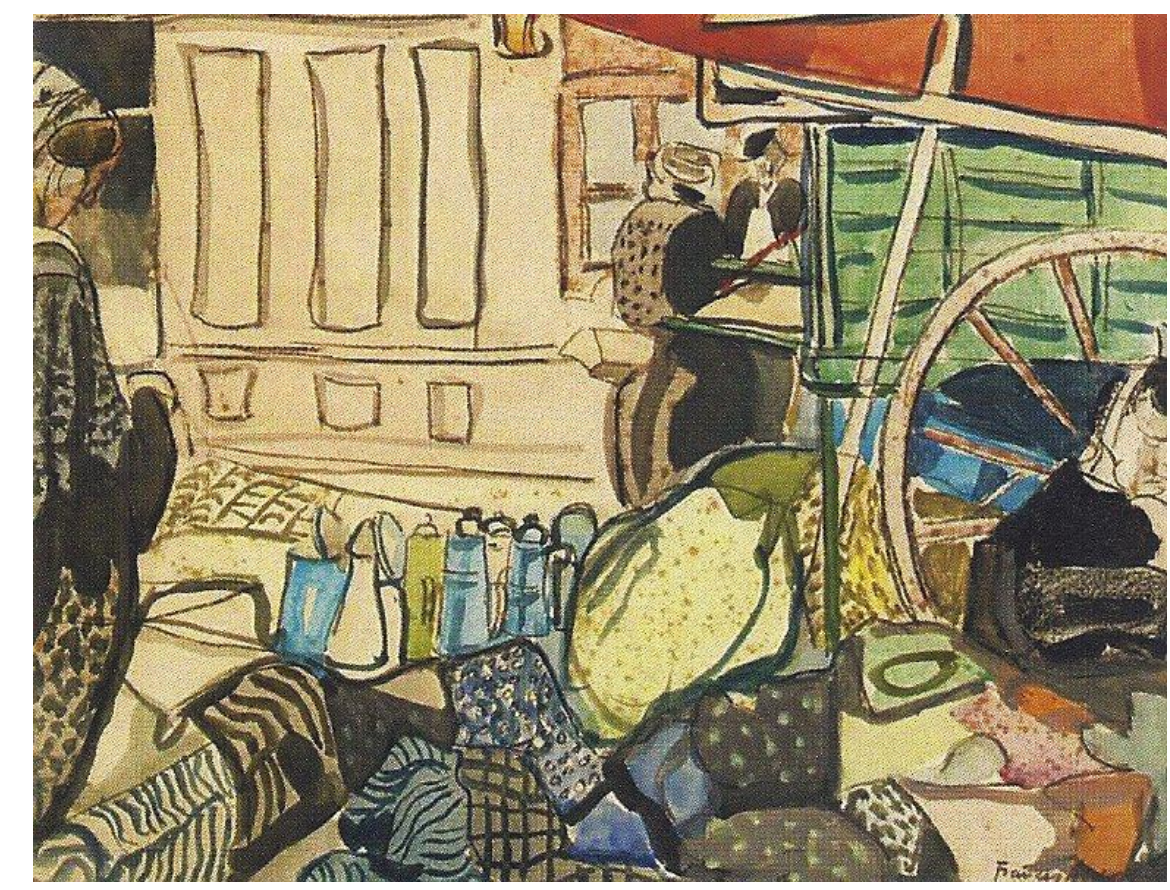

Figure 6. Frances Hodgkins, The Rag Market, Douarnenez, Finistère (1921), $25.6 \times 32.6 \mathrm{~cm}$, Field Collection.

Though in this batch of work she refreshed the familiar market theme, then, and arguably paved the way for her final success, it is evident from her correspondence that Hodgkins was at this time fundamentally tired of the onerous processes required by her situation, which had begun back in 1901 and in the reiteration of which now, twenty years later, she may well have felt her failure to achieve ongoing professional success. Her last new market-based works seem to have been the 1924 views of the market in Nice, whose whereabouts are not currently known, and these were undertaken expressly to milk earlier public preferences in order to realise quick sales (see note 46). Although a painting made in 1927 is known as Market at Concarneau (Te Papa Tongarewa), in a somewhat melancholy coda to her long habit of working sur le motif in the thick of her subject, it seems to have been painted from a window of the artist's hotel room, where ill health hampered her activity. ${ }^{53}$ Here, the old subject has seamlessly worked its way into an anticipation of what was to prove her big idea of the next decade, the open window and its embrace of both landscape and still life.

It is clear, then, that the motif of the marketplace yielded much to Frances Hodgkins over the years, and her investment in it reveals much about her often contradictory practice. In considering her adoption of this well-established motif, it must be wondered how much she knew of the precedents rehearsed briefly at the start of this essay. The field was very crowded 
in the years when she was trying to find her feet, but her intention was not necessarily to tread new ground, and she did not explore all the market's possibilities as she strove to establish her name and some financial stability. She may have thought that there was no need to emulate someone such as her exact contemporary Blanche MacManus, who turned her painterly skills to travel publications in 1903, placing her works as guide book illustrations, ${ }^{54}$ and that she would find some way to stay afloat in the huge pond of travelling artists whose works filled the calendar of the London dealers like The Fine Arts Society year after year until the war. Then that horrible event formed a painful hiatus in her career (as in others'), and there was widespread bewilderment in artistic circles thereafter as to how to rebuild a professional practice. When, in the 1930s, Hodgkins narrowed her focus to landscape and still life, this motif which had served her well for so long did eventually disappear from her repertoire, as did other figure subjects; and, significantly, it got absolutely no mention in the first publication to promote Hodgkins's achievement, Myfanwy Evans' monograph for Penguin that, prepared with the artist's approval, appeared in $1948 .{ }^{55}$ But the market is one of a number of sustained leitmotifs in Hodgkins's oeuvre, continuities in a heterogeneous mass of activity: it links her with contemporary trends in New Zealand and Europe whilst showcasing her individual development; it shows both her adaptability and her limitations; and it hosted her transformation from a New Zealand artist into a European one.

\footnotetext{
${ }^{1}$ E. H. McCormick, The Expatriate: A Study of Frances Hodgkins and New Zealand (Wellington: New Zealand University Press, 1954), 76. Anyone studying the life and work of Frances Hodgkins must be hugely indebted to McCormick's pioneering work; Linda Gill's edited selection of the artist's letters, cited frequently here, is also an invaluable resource for the researcher. I also appreciate the feedback of the two reviewers who read the first version of this essay.

${ }^{2}$ Henry Blackburn, Artistic Travel: A Thousand Miles Towards the Sun (London: William Clowes and sons, 1892), 4.

${ }^{3}$ For this general trend, see Kenneth McConkey, Peasantries (Newcastle upon Tyne: Newcastle Polytechnic Art Gallery, 1981), and for the context, Michael Jacobs's classic text, The Good and Simple Life: Artist Colonies in Europe and America (Oxford: Phaidon, 1985). For Osborne's context, see Julian Campbell, The Irish Impressionists: Irish Artists in France and Belgium, 1850-1914 (Dublin: National Gallery of Ireland, 1984).

${ }^{4}$ Langley was a Newlyn artist whom Hodgkins could well have met once she got to Penzance early in 1902: for this work and other comparable examples, see Another Cornwall/Gens de(s) Cornouaille(s) (Penzance: Penlee Gallery/Quimper: Musée Breton, 2012).

${ }^{5}$ The motif was not viable on the home front: "As towns and cities were established, land was often set aside for a local market, and some market halls were built, but none of them flourished. People were happy to buy food from local shops, or from sellers who hawked food door to door. Most communities had their local greengrocer, butcher, fish shop and grocer." Perrin Rowland, "Markets," Te Ara-The Encyclopedia of New Zealand, http://www.TeAra.govt.nz/en/markets

${ }^{6}$ Nerli left New Zealand in 1898 and his use of the subject seems to date to 1904-09. Such works include Old Venezia, Leghorn (Dunedin Public Art Gallery [DPAG]) Market Day, Rome (Te Papa), Italian Market Scene (private collection Auckland), and The Flower Market (private collection Australia).

${ }^{7}$ Henry Blackburn, Breton Folk: An Artistic Tour of Brittany (London: Samson, Lowe, Marston, Searle and Rivington, 1880). Blackburn was a leading English writer on contemporary art, and this is a book likely to have been in W. M. Hodgkins's library, along with his others such as Artistic Travel.
} 
${ }^{8}$ See "Caudebec-en-Caux," in Sketching Grounds, ed. Charles Holme, (London: The Studio, 1909), 153-64. This anthology also had a chapter on Morocco, which Hodgkins was to visit in 1903 ("The Atmosphere of Morocco," 143-52).

${ }^{9}$ Charles Gibson, Little Pilgrimages among French Inns (Boston: L. C. Page and co., 1905), 110.

${ }^{10}$ See also "Woman Selling Vegetables at a Street Market" and "Street Vegetable Stall in an Unidentified Town," PA1-0-764, Alexander Turnbull Library.

${ }^{11}$ Christopher Lloyd, "The Market Scenes of Camille Pissarro," National Gallery of Victoria, Art Journal 25, no. 10 (1985): 1-23.

${ }^{12}$ For instance, Apple Market, Landerneau, Brittany, 1878; Fishmarket, St Malo, c. 1880. Lhermitte's treatment of the subject can be said to have climaxed in the commission to paint Paris's famous central market Les Halles for the capital's City Hall (1889-95).

${ }^{13}$ Frances Hodgkins [FH] to Rachel Hodgkins, 26 August 1901, in The Letters of Frances Hodgkins, ed. Linda Gill (Auckland: Auckland University Press, 1993), 97.

${ }^{14}$ FH to Rachel Hodgkins, 26 August 1901, in Gill, Letters, 97.

${ }^{15}$ FH to Isabel Field, 6 November 1901, in Gill, Letters, 105.

${ }^{16}$ This could have been any of the several works of this subject now known.

${ }^{17}$ Richard Thomson, Camille Pissarro: Impressionism, Landscape and Rural Labour (London: South Bank Centre/Herbert Press, 1990), 66.

${ }^{18}$ Arthur Melville is a good example of this latter type, of whom Hodgkins was well aware: see Kenneth McConkey and Charlotte Topsfield, Arthur Melville: Adventures in Colour (Edinburgh: National Galleries of Scotland, 2015).

${ }^{19}$ The sketch referred to is no. 211 in E. H. McCormick, Works of Frances Hodgkins in New Zealand (Auckland: Auckland City Art Gallery, 1954), 180.

${ }^{20}$ Thus, while in Paris in 1901, "I have been getting up at 5.30 every morning to finish my sketches which I was unable to finish at Caudebec as the last week I was seedy and could not paint so I brought them with me to Paris" (FH to Isabel Field, 15 September 1901, in Gill, Letters, 99). Differing prices at exhibition indicate, however, that she may have put her studies and sketches up for sale as well as the more finished scenes.

${ }^{21}$ FH to Rachel Hodgkins, 28 July 1902, in Gill, Letters, 133.

${ }^{22}$ For example, Street Scene (1901, ex Dunbar Sloane); Cobbled Streets with old Houses (1901, whereabouts unknown); La Place, Arles (1902, Hocken Collections); Rue d'Horloge, Dinan (1902?); Street Scene in Holland (1903, Te Papa Tongarewa).

${ }^{23}$ FH to Isabel Field, 30 September 1902, in Gill, Letters, 138.

24 “Otago Art Society," Otago Daily Times, 14 November 1902, 3.

25 "Otago Art Society's Exhibition," Otago Daily Times, 7 November 1903, 2.

${ }^{26}$ Exhibition of Oil and Water Colour Paintings by Miss Hodgkins and Miss D. K. Richmond, February-March 1904, at McGregor Wright and Co, 129 Lambton Quay. Seven exhibits named as Dinan subjects were market scenes, while several further exhibits had markets as their subject.

${ }^{27}$ See Joel L. Schiff, Grace Joel: An Impressionist Portrait (Dunedin: Otago University Press, 2014), 75, 78; also no. 22 in Grace Joel: Paintings and Drawings (Dunedin: DPAG, 1980).

${ }^{28}$ Some of these artists' works are examined by Adrienne Dempsey in her thoughtful survey of the topic; she also considers Robert Procter and John Weeks. Adrienne Dempsey, "To Market:

Representation of the Market-Place by New Zealand Expatriate Artists 1900-1939," (unpublished Masters thesis, University of Canterbury, 2012).

${ }^{29}$ Norman Garstin, "Tangier as a Sketching Ground," The Studio 11 (August 1897): 177-82.

${ }^{30}$ FH to Dorothy Kate Richmond, 3 December 1902, in Gill, Letters, 151.

${ }^{31}$ FH to Rachel Hodgkins, 12 January 1903, in Gill, Letters, 152.

32 "Life in the City," Wairarapa Daily Times, 1 March 1904, 6.

${ }^{33}$ Garstin, "Tangier," 177.

${ }^{34}$ The so-called Pottery, Tangier Market (1902-03), showing a female vendor, has now been recognised as a French scene, its title amended to Pottery Market (Dunbar Sloane, August 2017).

${ }^{35}$ This was commissioned by the Theomins, Dunedin acquaintances encountered by chance on the journey; it is not known if the patron dictated the subject.

Journal of New Zealand Studies NS27 (2018), 74-91

https://doi.org/10.26686/inzs.v0iNS27.5177 
${ }^{36}$ Nos. 388 and 389, respectively; the exhibition closed on 30 April, and Hodgkins arrived back in London, by her own account, on 26 April; FH to Rachel Hodgkins, 1 May 1903, in Gill, Letters, 164.

${ }^{37}$ FH to DKR, 23 March 1903, in Gill, Letters, 157.

${ }^{38}$ FH to Rachel Hodgkins, 11 June 1903, in Gill, Letters, 165.

${ }^{39}$ FH to Rachel Hodgkins, 22 July 1903, MS-1017, Alexander Turnbull Library.

${ }^{40}$ FH to Rachel Hodgkins, 23 September 1903, in Gill, Letters, 172. It can be speculated that the reason these works are not currently traced is that they were successful on exhibition (Dunedin November 1903, Wellington February 1904) and have remained in private hands.

${ }^{41}$ Quoted in Julie Heraud, Maud Sherwood, New Zealand Artist (unpublished typescript 1992), 34. For a summation of artists in the Concarneau marketplace, see René le Bihan, La Route des Peintres en Cornouaille (Quimper: Editions Palantines, 2005), 42ff.

${ }^{42}$ See Julie King, Sydney Lough Thompson at Home and Abroad (Christchurch: Robert McDougall Art Gallery, 1990), 33. A comparison between Thompson's and Hodgkins's work could most nicely be made by examining their respective Concarneau works, but Hodgkins seems to have eased off the marketplace there (1912-13) in favour of beach and harbour scenes, few of which are currently known. Dempsey gives considerable attention to this question.

${ }^{43}$ Letter from Paris dated 7 December 1919, quoted in Bettina MacAulay, Songs of Colour: The Art of Vida Lahey (Queensland Art Gallery, 1989), 87.

${ }^{44}$ For Hodgkins's exhibition record, see Roger Collins and Iain Buchanan, Frances Hodgkins on Display: Galleries, Dealers and Exhibitions 1890-1950, Bulletin of New Zealand Art History special series no. 5 (Dunedin: Hocken Library, 2000).

${ }^{45}$ This could have been any of the aforementioned works of this subject.

${ }^{46}$ See "A Notable Exhibition," Melbourne Argus, 22 November 1912, 6, and "Notes and Notices," The Australasian, 7 December 1912, 40.

${ }^{47}$ FH to Rachel Hodgkins, 5 April 1914, MS-5292-126, Alexander Turnbull Library.

48 "I can't face another rough winter of this semi-bankruptcy . . . having made this decision I want to spend the Summer making attractive best-selling pictures - such as flower markets \& red sails \& blue Mediterranean - they used to lap up this sort of thing in the good old time." FH to Hannah Ritchie, 17(?) April 1924, in Gill, Letters, 378.

${ }^{49}$ Garstin, "Tangier," 177.

${ }^{50}$ See, for instance: "I have vowed a vow not to return till I have written the name of Frances Hodgkins in capital letters across - is it the scroll of fame or what that we are all so anxious to sign." (FH to Kate Rattray, 27 August 1901, in Gill, Letters, 76); and "I am glad Miss Richmond is looking well and doing well - brave dear woman — she doesn't care a snap for the world. I do. I do. I do." (FH to Rachel Hodgkins, 10 June 1909, in Gill, Letters, 192).

${ }^{51}$ See the author's Frances Hodgkins People (Wellington: New Zealand Portrait Gallery, 2017).

${ }^{52}$ Lydia Pharazyn to William and Isabel Field, undated postcard, MS-0113-01/41, Alexander Turnbull Library.

${ }^{53}$ A work exhibited in 1928 as Normandy Vegetable Market (CSA, no. 372) was undoubtedly not a new piece. Also, Auckland Art Gallery's undated A Market Scene is probably from the early 1920s. ${ }^{54}$ This was after marrying M. F. Mansfield, who provided the texts in a series of titles that reflected the itinerary followed by Hodgkins and so many others in the prewar years: see Francis Miltoun, illus. by Blanche MacManus, The Cathedrals of Northern France, 1903; Rambles on the Riviera, 1906; In the Land of Mosques and Minarets, 1908, etc. It can be remarked that Hodgkins, staying single, remained a free agent.

${ }^{55}$ Myfanwy Evans, Frances Hodgkins (London: Penguin Books, 1948). Although it did not appear until after her death, the project was begun in 1942 and Hodgkins read and approved both text and choice of illustrations. 